\title{
Ganoderma lucidum Spores Powder Capsule
}

National Cancer Institute

\section{Source}

National Cancer Institute. Ganoderma lucidum Spores Powder Capsule. NCI Thesaurus.

Code C118365.

An orally available powder-based nutritional supplement containing the spores of the mushroom Ganoderma lucidum (Ganoderma I.), a traditional Chinese medicine, with potential protective, sedative, anti-oxidant, immunomodulating, and antineoplastic activities. The spores contain various bioactive components including polysaccharides, triterpenoids, peptidoglycans, amino acids, fatty acids, vitamins, and minerals. Upon oral administration of the Ganoderma lucidum spores powder capsule, the active ing redients may modulate the immune system, may activate dendritic cells, natural killer cells, and macrophages and may modulate the production of certain cytokines, such as tumor necrosis factor-alpha (TNFa), interleukin (IL) 1-beta (IL-1b), IL-2, IL-6 and IL-8. This supplement may improve cancer-related fatigue and may be used as a sleep aid; it may also have a beneficial effect on the heart, lung, liver, pancreas, kidney, and the central nervous system. 